\title{
Effects of processing and the physical form of diets on digestibility and the performance of nursery piglets
}

\author{
Efeito do processamento e da forma física da ração sobre o \\ desempenho de leitões na fase de creche e digestibilidade da dieta
}

\author{
Kelly Mazutti ${ }^{1 *}$; Everton Luis Krabbe ${ }^{2}$; Diego Surek ${ }^{2}$; Alex Maiorka ${ }^{3}$
}

\begin{abstract}
The aim of this study was to assess the influence of various diet processing methods and physical forms on digestibility and zootechnical performance parameters of nursery piglets. The study was performed in 2 phases. The first phase was performed twice with 120 piglets per experiment, for a total of 240 newly weaned piglets, in a randomized block design with 6 treatments and 5 replicates (30 pens). The following experimental diets were offered from weaning to 21 days after weaning (initial nursery phase) and included the following: mash diet (M); mash diet conditioned at $60^{\circ} \mathrm{C}(\mathrm{CM})$; diet pelleted at $60^{\circ} \mathrm{C} /$ matrix $2.5 \mathrm{~mm}(\mathrm{P} 2.5)$; diet pelleted at $60^{\circ} \mathrm{C} /$ matrix $2.5 \mathrm{~mm}$ and crumbled (P2.5C); diet pelleted at $60^{\circ} \mathrm{C} /$ matrix $4.75 \mathrm{~mm}(\mathrm{P} 4.75)$; and diet pelleted at $60^{\circ} \mathrm{C} /$ matrix $4.75 \mathrm{~mm}$ and crumbled (P4.75C). The animals' daily weight gain (DWG), daily feed intake (DFI) and feed conversion (FC) were assessed. Phase 2 used 24 piglets (33 days old) from Phase 1, which were lodged in individual metabolic cages. The experiment employed a randomized block design with 4 treatments and 6 replicates: mash diet (M); mash diet conditioned at $60^{\circ} \mathrm{C}(\mathrm{CM})$; diet pelleted at $60^{\circ} \mathrm{C} /$ matrix $2.5 \mathrm{~mm}(\mathrm{P} 2.5)$; and diet pelleted at $60^{\circ} \mathrm{C} /$ matrix $4.75 \mathrm{~mm}(\mathrm{P} 4.75)$. Feces were collected to analyze the digestibility of and apparent digestible energy in dry matter, gross energy and ether extract. The processing and physical form of the diets did not affect the DWG and DFI of the 21- to 39-day-old piglets. The 2.5-mm-diameter pellets induced better FC compared to the crumbled and conditioned crumbled diets $(\mathrm{P}<0.05)$, which might be attributed to the better digestibility of the ether extract in the pelleted diets. Pellet size had no effect on the performance parameters.
\end{abstract}

Key words: Ether extract. Feeding. Pellet. Swine. Weaning.

\section{Resumo}

O objetivo deste trabalho foi avaliar a influência de diferentes tipos de processamento e forma física da ração sobre a digestibilidade e parâmetros de desempenho zootécnico de leitões na fase de creche. $\mathrm{O}$ estudo foi conduzido em duas etapas. A primeira etapa foi repetida no tempo, com 120 leitões em cada experimento, totalizando 240 leitões recém-desmamados, num delineamento experimental em blocos ao acaso, com seis tratamentos e cinco repetições (30 baias). As dietas experimentais foram ofertadas do desmame aos 21 dias pós-desmame (fase inicial de creche), sendo: dieta farelada (F); dieta condicionada $60^{\circ} \mathrm{C}$ (FC); dieta peletizada $60^{\circ} \mathrm{C} /$ matriz $2,5 \mathrm{~mm}(\mathrm{P} 2.5)$; dieta peletizada $60^{\circ} \mathrm{C} /$ matriz $2,5 \mathrm{~mm}$ e triturada (P2.5T); dieta peletizada $60^{\circ} \mathrm{C} /$ matriz $4,75 \mathrm{~mm}(\mathrm{P} 4.75)$; dieta peletizada $60^{\circ} \mathrm{C} /$ matriz 4,75 $\mathrm{mm}$ e triturada (P4.75T). Foi determinado o ganho de peso diário (GPD), o consumo de ração diário

\footnotetext{
${ }^{1}$ Prof $^{\mathrm{a}}$, Assistente III, Curso de Medicina Veterinária, Escola de Ciências Agrária e Medicina Veterinária, Pontifícia Universidade Católica do Paraná, PUCPR, Curitiba, PR, Brasil. E-mail: kelly.mazutti@pucpr.br

2 Pesquisadores, Empresa Brasileira de Pesquisa Agropecuária, EMBRAPA, Centro Nacional de Pesquisa de Suínos e Aves, Concórdia, SC, Brasil. E-mail: everton.krabbe@embrapa.br; diego.surek@embrapa.br

${ }^{3}$ Prof. Associado, Departamento de Zootecnia, Universidade Federal do Paraná, UFPR, Curitiba, PR, Brasil. E-mail: amaiorka@ ufpr.br

* Author for correspondence
} 
(CRD) e a conversão alimentar (CA). Na segunda etapa foram utilizados 24 animais (33 dias de idade), provenientes da primeira etapa, os quais foram alojados individualmente em gaiolas metabólicas. $\mathrm{O}$ delineamento experimental foi inteiramente ao acaso, com quatro tratamentos de seis repetições cada: dieta farelada (F); dieta condicionada $60^{\circ} \mathrm{C}(\mathrm{FC})$; dieta peletizada $60^{\circ} \mathrm{C} /$ matriz $2,5 \mathrm{~mm}(\mathrm{P} 2.5)$; dieta peletizada $60^{\circ} \mathrm{C} /$ matriz $4,75 \mathrm{~mm}(\mathrm{P} 4.75)$. Foram realizadas coletas de fezes para determinação da digestibilidade da matéria seca, energia digestível aparente na matéria seca, energia bruta e extrato etéreo. O processamento e a forma física da ração não afetaram o GPD e CRD dos leitões dos 21 aos 39 dias de idade. A peletização a $2,5 \mathrm{~mm}$ de diâmetro proporcionou melhor CA em comparação às rações farelada e farelada condicionada $(\mathrm{P}<0.05)$, o que pode ser atribuído a maior digestibilidade do extrato etéreo nas dietas peletizadas. $\mathrm{O}$ tamanho do pelete não teve efeito sobre os parâmetros de desempenho.

Palavras-chave: Alimentação. Desmame. Extrato etéreo. Pelete. Suínos.

\section{Introduction}

The agro-industry is continuously seeking to increase the profitability of production systems. As animal feed accounts for 70 to $80 \%$ of the production costs and environmental liabilities in swine production, technologies aimed at sustainability are crucial.

Diet processing is one of the options available to improve the zootechnical performance of animals. In addition to grinding, several processing methods that determine the physical form of diets are commercially available, such as pelleting, extrusion, expansion and a combination of these methods (KIL; STEIN, 2010). Both costs and outcomes are factors that determine the method for processing pre-initial piglet diets (SUREK, 2012).

Some studies have investigated the effect of pelleting on the zootechnical performance of piglets, but few of them have a complete description of the pelletization process. The available information on pelleting has generally been derived from empirical results, the characterization of the production parameters has been flawed, and the full process has been poorly described. Steidinger et al. (2000) only assessed several conditioning temperatures for postweaning diets but did not describe corn particle size. Medel et al. (2004) compared the preprocessed ingredients of mash or pellet diets and described only the sieve used to grind the corn, tested a single conditioning temperature $\left(70^{\circ} \mathrm{C}\right)$ and did not indicate the time. Lavorel et al. (1982), Patridge (1989), Traylor et al. (1996), Edge et al. (2005) and Costa et al. (2006) tested different diameters of pellets, but did not perform a detailed characterization of the processing parameters. Since pelletization is influenced by many variables, a complete description of process is essencial to unsderstand and reproduces the researches.

Although pelleting is widely employed for animal feeds, manufacturers face difficulties in the actual production of pelleted diets, as they lack proper processing conditions under different settings. Therefore, the aim of the present study was to assess the influence of several processing methods and the physical form of the diets on performance of nursery pigs and on the digestibility of the diets.

\section{Materials and Methods}

The experimental procedures involving animals were approved by the animal use ethics committee of Federal University of Paraná, ruling no. 031/2015. The study was divided into 2 phases: Phase 1 , the zootechnical performance assessment, and Phase 2, the digestibility assessment. All the animals were fed the same pre-initial diet (Table 1). 
Table 1. Composition of the pre-initial diet used in the postweaning phases.

\begin{tabular}{lc}
\hline \multicolumn{1}{c}{ Ingredient } & Amount, $\mathrm{g} / \mathrm{kg}$ \\
\hline Corn & \\
Soy bran & 412.2 \\
Piglet premix (Aurotron 250$)^{2}$ & 257.0 \\
Crystal sugar & 250.0 \\
Degummed soybean oil & 50.0 \\
DL-methionine & 30.0 \\
L-lysine & 0.6 \\
& 0.2 \\
\hline
\end{tabular}

${ }^{1}$ Corn with geometric mean diameter (dgw) of $622 \mu \mathrm{m}$ and geometric standard deviation (Sgw) of 2.13.

${ }^{2}$ Guaranteed analysis per kg of product: folic acid (min) $3.30 \mathrm{mg}$; pantothenic acid (min) $72.00 \mathrm{mg}$; Bacillus licheniformis/2.56 x 106 colony forming units (CFU)/g; Bacillus subtilis/2.56 x 106 CFU/g; biotin (min) $0.54 \mathrm{mg}$; calcium (max) $27 \mathrm{~g}$; calcium (min) $25 \mathrm{~g}$; chloro-hydroxyquinoline $489 \mathrm{mg}$; copper ( $\mathrm{min}) 800 \mathrm{mg}$; ether extract (min) $92.01 \mathrm{~g}$; iron (min) $382.32 \mathrm{mg}$; crude fiber ( $\max$ ) $25.04 \mathrm{~g}$; phosphorus (min) $19.95 \mathrm{mg}$; iodine ( $\mathrm{min}) 4.80 \mathrm{mg}$; lysine (min) $20.15 \mathrm{~g}$; manganese (min) $239.46 \mathrm{mg}$; mineral matter (max) $159.59 \mathrm{~g}$; methionine $(\mathrm{min}) 10.03 \mathrm{~g}$; niacin $(\mathrm{min}) 150.00 \mathrm{mg}$; crude protein $(\mathrm{min}) 160.00 \mathrm{~g}$; selenium (min) $1.40 \mathrm{mg}$; sodium (min) 9,300.00 mg; threonine (min) $12.48 \mathrm{~g}$; tryptophan $(\min )$ 2, $419.90 \mathrm{mg}$; wetness $(\max ) 61.37 \mathrm{~g}$; vitamin A (min) 46,000.00 IU; vitamin B1 (min) $7.20 \mathrm{mg}$; vitamin B12 (min) $94.00 \mu \mathrm{g}$; vitamin B2 (min) $20.40 \mathrm{mg}$; vitamin B6 (min) $14.00 \mathrm{mg}$; vitamin D3 (min) 8,400.00 IU; vitamin E (min) $135.00 \mathrm{IU}$; vitamin $\mathrm{K} 3(\mathrm{~min}) 12.08 \mathrm{mg}$; and zinc ( $\mathrm{min}) 8,000 \mathrm{mg}$.

\section{Preparation of the diets}

All the experimental diets used in the present study had the same composition but were processed differently as shown in Table 2.

On the day the diets were prepared, the average temperature was $14.9^{\circ} \mathrm{C}$, and the average humidity was $83.4 \%$. The $\mathrm{M}$ diet was simply mixed in a horizontal mixer and bagged. To prepare the CM diet, $\mathrm{M}$ was steam conditioned (1.2-m length $\mathrm{x}$ 0.23-m diameter; 3 -s retention time) at a constant temperature $\left(60^{\circ} \mathrm{C}\right)$ and cooled on a canvas extended on the crumbled diet; the feed was bagged the following day. The P2.5 diet was prepared by steam conditioning the $\mathrm{M}$ diet at $60^{\circ} \mathrm{C}$, which was then pelletized using a Koppers Junior C40 pelletizing device with a 50 HP engine and a $40-$ $\mathrm{mm}$ thick matrix with a $2.5-\mathrm{mm}$ diameter hole. To prepare the $\mathrm{P} 2.5 \mathrm{C}$ diet, the $\mathrm{P} 2.5$ was crumbled using a roller mill. The $\mathrm{P} 4.75$ diet was prepared using the aforementioned pelletizing device; however, the diet was steam conditioned at $60^{\circ} \mathrm{C}$, and the matrix had a diameter hole and thickness of $4.75 \mathrm{~mm}$ and $50 \mathrm{~mm}$, respectively. To prepare the $\mathrm{P} 4.75 \mathrm{C}$ diet, the $\mathrm{P} 4.75$ was crumbled using a roller mill. The pelleted diets were cooled in a vertical cooler until the pellet mass temperature was $8^{\circ} \mathrm{C}$ above room temperature.

Table 2. Description of the experimental treatments.

\begin{tabular}{lc}
\hline \multicolumn{1}{c}{ Treatment } & Diet processing and physical form \\
\hline $\mathrm{M}$ & Mash diet \\
$\mathrm{CM}$ & Mash diet conditioned at $60^{\circ} \mathrm{C}$ \\
$\mathrm{P} 2.5$ & Diet conditioned at $60^{\circ} \mathrm{C} /$ pelleted $/ 2.5 \mathrm{~mm}$ matrix \\
$\mathrm{P} 2.5 \mathrm{C}$ & Diet conditioned at $60^{\circ} \mathrm{C} /$ pelleted $/ 2.5 \mathrm{~mm}$ and crumbled \\
$\mathrm{P} 4.75$ & Diet conditioned at $60^{\circ} \mathrm{C} /$ pelleted $/ 4.75 \mathrm{~mm}$ matrix \\
$\mathrm{P} 4.75 \mathrm{C}$ & Diet conditioned at $60^{\circ} \mathrm{C} /$ pelleted $/ 4.75 \mathrm{~mm}$ and crumbled \\
\hline
\end{tabular}


The feeder rotation speed was measured and kept constant throughout the preparation of the pelleted diets. To determine the production efficiency of the pelleting device, the time required for pelleting 500 $\mathrm{kg}$ of feed was measured, and the current amperage was registered at 1-min intervals. The electric energy consumption $(\mathrm{kWh})$ was calculated using the following equations: $\mathrm{I}=\mathrm{P} / \mathrm{V}$ and $\mathrm{kWh} /$ ton $=$ ( $\mathrm{P} \times$ pelletizing time $) / 1000$, where $\mathrm{I}=$ current, $\mathrm{P}=$ power $(\mathrm{W})$ and $\mathrm{V}=$ voltage $(380 \times \sqrt{ } 3)$.

Following the preparation of the diets, a representative sample was taken to analyze the following parameters: dry matter, water activity, water absorption rate, angle of repose, color ( $\mathrm{L}^{*}$, $a^{*}$, and $b^{*}$ ), bulk density, pellet unit density, percent fines, pellet durability index (PDI), geometric mean diameter (GMD) and geometric standard deviation (GSD) of particles in the same physical form as it was produced.

The dry mass of the diets was determined by weighing approximately $2 \mathrm{~g}$ of the corresponding sample, which was placed in a stove at $110^{\circ} \mathrm{C}$ for 12 $\mathrm{h}$ and then weighed again. The water activity was measured using the Aqualab ${ }^{\circledR}$ device (Decagon Devices, Inc., Pullman, WA, USA).

To calculate the water absorption rate, a 5-g sample of each diet was placed on a paper filter and immersed in a $50-\mathrm{ml}$ beaker containing $20 \mathrm{ml}$ of water. The beaker was shaken for $15 \mathrm{~s}$ and allowed to rest for another $15 \mathrm{~s}$. The samples were then removed, allowed to drain for $1 \mathrm{~min}$ and weighed. The water absorption rate was calculated based on the percentage of retained water.

To measure the angle of repose, the diets were carefully made to flow through a funnel with a $1.5-\mathrm{cm}$ radius, which was located $15 \mathrm{~cm}$ from the base. The diets formed cone-shaped piles on the surface, and the angle of repose was determined by measuring the height " $h$ " and radius " $r$ " of the circular bases of the piles. The following equation was used to calculate the angle of repose: tan-1 (h / r).
The color of the diets was determined with a spectrophotometer (portable CR-400 Chroma Meter, Konica Minolta Sensing, INC.) using color space $L^{*} a^{*} b^{*}$, where $L^{*}$ measures brightness, $a^{*}$ measures the tendency to red/green, and $b^{*}$ measures the tendency to blue/yellow. To perform this analysis, a small glass plate $(5 \mathrm{~cm}$ in diameter; $1.5 \mathrm{~cm}$ in height) was filled and placed under the spectrophotometer on a white surface.

The bulk density was determined using a standard hectoliter, filling a metallic cylinder (250 $\mathrm{ml})$. The excess on the top of the container was removed by sliding a metallic plate along the top edge of the cylinder. The weight of both the cylinder and its content was recorded, and the bulk density was calculated $\left(\mathrm{kg} / \mathrm{m}^{3}\right)$. The pellet unit density was calculated by dividing the mass of 20 pellets by their volume.

To determine the percent fines, $300 \mathrm{~g}$ of the pelleted diets was weighed and sieved for approximately $30 \mathrm{~s}$ using 2.0 - and $4.0-\mathrm{mm}$ sieves (Tyler no. 9 and 5, respectively, Telastem Peneiras para Análises LTDA) for the P4.75 diet and a 2.0$\mathrm{mm}$ sieve for the P2.5 diet. The percent fines were expressed as the percentage of fines retained in the sieve relative to the initial weight of the diets.

The pellet durability index (PDI), or the percentage of unbroken pellets, was assessed using a PDI determination device, which consisted of 5 rotating boxes $(30 \mathrm{~cm}$ in height; $12.5 \times 12.5-\mathrm{cm}$ base). Approximately $150 \mathrm{~g}$ of the pellets retained in the sieves during the determination of the percent fines $(4.0-\mathrm{mm}$ sieve for P4.75 and 2.0-mm sieve for P2.5, Tyler no. 9 and 5, respectively, Telastem Peneiras para Análises LTDA) was tested in the boxes that composed the PDI determination device at 50 rotations per minute $(\mathrm{rpm})$ for $10 \mathrm{~min}$. Next, the samples were sieved $(4.0-\mathrm{mm}$ sieve for P4.75 and 2.0-mm sieve for P2.5) for approximately 30 $\mathrm{s}$ to remove the fines and the broken pellets. The PDI was expressed as a percentage. Hardness was measured in 20 pelletized (1-cm long) particles using a 298 / DGP durometer (Nova Ética). 
The GMD and GSD of the particles were determined following the procedure described by Zanotto and Bellaver (1996) using Granucalc software (ZANOTTO et al., 2013): 100 to $200 \mathrm{~g}$ samples of the diets were dried in a stove at $105^{\circ} \mathrm{C}$ for $12 \mathrm{~h}$. Next, the samples were sieved through a set of 6 superposed sieves that were $0.15,0.30,0.60$, 1.0, 2.0 and $4.0 \mathrm{~mm}$ in diameter (Tyler no. 100, 48, 28, 14, 9 and 5, respectively, Telastem Peneiras para Análises LTDA) coupled to the "Produteast" vibration device for $10 \mathrm{~min}$ at $80 \%$ of the maximum vibration capacity.

\section{Phase I-zootechnical performance experiment}

This phase was performed twice, with 120 piglets used in each experiment, totaling 240 newly weaned male and female animals (21 days old, on average). The animals were individually weighed at birth, when housed (at 21 days of age) and at 33, 39 and 53 days of age. One animal was removed from each pen on the second week of the first experiment (33 days of age) for the digestibility assay (Phase 2). Therefore, 4 animals per pen were used during the first 12 days of the study, and 3 animals per pen were used during the subsequent phase.

The piglets were accommodated in 2 nursery rooms; each room measured $8 \times 12.40 \mathrm{~m}$ and contained 16 concrete pens. Each pen had an area of $3.75 \mathrm{~m}^{2}$ and was divided with a partition into 2 compartments. In 1 of the compartments, the floor was covered by shavings, and the animals had access to an automatic trough feeder made of aluminum. The animals kept in the other type of compartment had access to a nipple and cup automatic drinker and were free to urinate and defecate, and the floor was partially slatted to make cleaning easier. The rooms were ventilated through windows on the front and back walls.

The experiment was a randomized block design with 6 treatments (Table 2) and 5 replicates for a total of 30 pens; the experiment was performed twice with a split plot arrangement. The experimental diets were introduced at the time of weaning, when the piglets were 21 days of age. From 39 to 53 days of age, all the piglets were fed an initial mash diet independent from the treatment previously given, to assess the residual effects of diets. The animals' WG, FI and FC were assessed.

\section{Phase II - digestibility experiment}

In this phase, 24 pigs (33 days old) from the first experiment in Phase 1 were used. The animals were individually maintained in metabolic cages for pigs $(1.21 \times 0.56 \times 0.85 \mathrm{~m})$. The room was maintained at approximately $22^{\circ} \mathrm{C}$. After a 5-day adaptation period, the animals' feces were collected for 5 days and were used to assess the apparent dry matter digestibility (ADMD), apparent digestibility coefficient of gross energy (ADCGE), apparent digestible energy in dry matter (ADEDM) and apparent digestibility coefficient of ether extract (ADCEE). In this phase, the animals were fed the pre-initial diet (Table 1).

Ferric oxide $\left(\mathrm{Fe}_{2} \mathrm{O}_{3}\right)$ was used as a fecal marker to establish the onset and end of the period of urine and feces collection. The diets were supplied at 8:00 am, and the total daily amount was based on the metabolic weight (live weight $-\mathrm{LW}^{0.75}$ ). The feed amount was adjusted to the 1 corresponding to the animal that had exhibited the minimum intake along the adaptation period to ensure that all the animals would consume equal amounts of nutrients per metabolic weight. The animals' feces were collected daily after feeding, placed in plastic bags and kept in a freezer $\left(-10^{\circ} \mathrm{C}\right)$. The feces were then thawed, homogenized and dried in a forced ventilation oven at $55^{\circ} \mathrm{C}$ until attaining constant weight. The dry feces and diets were ground to $1 \mathrm{~mm}$ and subjected to an analysis of dry matter (DM) at $105^{\circ} \mathrm{C}$, ether extract and gross energy, the latter using a calorimetric bomb, according to the methods described by Silva (1990).

The experiment was a randomized block design with 4 treatments $(\mathrm{M}$ - mash diet, $\mathrm{CM}$ - mash diet 
conditioned at $60^{\circ} \mathrm{C}$; P2.5 - diet pelleted at $60^{\circ} \mathrm{C} /$ matrix $2.5 \mathrm{~mm}$; and $\mathrm{P} 4.75$ - diet pelleted at $60^{\circ} \mathrm{C} /$ matrix $4.75 \mathrm{~mm}$ ) selected in Phase 1 and 6 replicates of 1 male animal each for a total of 24 animals.

\section{Statistical analysis}

Processing was characterized by means of descriptive statistics. The performance and digestibility data were first tested for homogeneity by means of Bartlett's test and then subjected to a blocked analysis of variance (ANOVA). Means were compared with Tukey's test at 5\% probability.

\section{Results and Discussion}

The production of the $4.75-\mathrm{mm}$ pellets was more efficient compared to the production of the $2.5-\mathrm{mm}$ pellets because the amount of feed produced per hour was higher and the electric energy consumption per ton of produced feed was lower (Table 3).

Table 3. Parameters of production and pelleting efficiency of pellets with diameters of $2.5 \mathrm{~mm}$ and $4.75 \mathrm{~mm}$.

\begin{tabular}{lcc}
\hline \multicolumn{1}{c}{ Item } & P2.5 & P4.75 \\
\hline Feeder rotation, rpm & 12.9 & 25.2 \\
Production, kg/h & 955 & 1652 \\
Current, A & $36.4 \pm 2.2$ & $23.2 \pm 0.8$ \\
Electric energy consumption, $\mathrm{kWh}$ & 23.9 & 15.3 \\
Production efficiency, kWh/ton & 25.06 & 9.21 \\
\hline
\end{tabular}

The DM percentage of the feeds decreased after 25 days of storage due to absorption of environmental moisture (Table 4). Such a difference $(\Delta)$ in DM percentage and water absorption rate was higher in the mash and crumbled diets compared to the pelleted diets, which is most likely due to the larger available contact surface for water absorption in the former. Another possible explanation is that the mash diets were produced dry, whereas the production of the pelleted diets involved the application of hot steam, resulting in increased wetness, which made them more resistant to water absorption.

The water absorption rate was twice as high in the pelleted/crumbled diets compared to the pelletized only diets. The reason is that the surface absorption is decreased in the pelleted diets due to the formation of pellets after processing, which makes water absorption difficult; this resistance, however, is disrupted in the course of grinding.

The M and P2.5 diets exhibited the largest and smallest angles of repose, respectively. A diet with a smaller angle of repose has higher flowability during transport and delivery (ROSENTRATER, 2006), which reduces feed waste.

Interestingly, when compared to mash diets, pelleting reduced the bulk density. Several authors (SKOCH et al., 1983a; BEHNKE, 2001) consider the opposite condition, i.e., an increase in the bulk density, to be one of the main advantages of pelleting as it optimizes the amount of feed that might be stored and/or transported in the same space compared to mash diets. The difference between the aforementioned studies might be due to the use of different feed ingredients. Several studies have used wheat and barley in the formulation of pig feeds, in contrast to the present study, which used corn and soybean. As ingredients, wheat and barley are more voluminous and less dense, so they most likely allow for greater compaction during the pelleting process, which increases the bulk density. 
Table 4. Physical description of diets and pellets.

\begin{tabular}{|c|c|c|c|c|c|c|}
\hline \multirow{2}{*}{ Item } & \multicolumn{6}{|c|}{ Treatment $^{1}$} \\
\hline & $\mathrm{M}$ & $\mathrm{CM}$ & $\mathrm{P} 2.5$ & $\mathrm{P} 2.5 \mathrm{C}$ & P4.75 & $\mathrm{P} 4.75 \mathrm{C}$ \\
\hline Dry matter, $\%^{\text {a }}$ & 90.04 & 87.89 & 88.97 & 89.51 & 88.08 & 88.47 \\
\hline Dry matter after 25 days of storage, $\%^{a}$ & 88.14 & 86.48 & 87.92 & 88.03 & 87.00 & 87.08 \\
\hline$\Delta$ dry matter & 1.9 & 1.41 & 1.05 & 1.48 & 1.08 & 1.39 \\
\hline Water activity, $\%$ a & 0.643 & 0.702 & 0.663 & 0.655 & 0.697 & 0.69 \\
\hline Water absorption rate, $\%$ a & 80.9 & 78.7 & 53.5 & 106.0 & 44.9 & 96.6 \\
\hline Angle of repose, ${ }^{\circ} \mathrm{b}$ & 30 & 21 & 16.5 & 17 & 18.5 & 19 \\
\hline \multicolumn{7}{|l|}{ Color ${ }^{b}$} \\
\hline $\mathrm{L}^{*}$ & 65.6 & 62.67 & 51.07 & 55.6 & 46.97 & 60.39 \\
\hline$a^{*}$ & 0.35 & 0.78 & 0.24 & 0.38 & 0.38 & 0.69 \\
\hline$b^{*}$ & 39.55 & 40.3 & 28.57 & 31.8 & 28 & 36.14 \\
\hline Bulk density, $\mathrm{kg} / \mathrm{m}^{3 \mathrm{~b}}$ & 714.47 & 647.43 & 592.48 & 628.67 & 584.73 & 613.05 \\
\hline Pellet unit density, $\mathrm{kg} / \mathrm{m}^{3 \mathrm{c}}$ & & & $1,093.27$ & & $1,060.97$ & \\
\hline Fines, $\%$ a & & & $1.86^{\mathrm{d}}$ & & $3.86^{\mathrm{d} / 7.80^{\mathrm{e}}}$ & \\
\hline Pellet durability index, $\%{ }^{a}$ & & & $99.19^{d}$ & & $96.62^{\mathrm{d} / 95.43^{\mathrm{e}}}$ & \\
\hline Hardness, $\mathrm{kgf}^{\mathrm{c}}$ & & & 6.7 & & 4.51 & \\
\hline GMD, $\mu \mathrm{m} / \mathrm{GSD}^{\text {a }}$ & $537 / 2.42$ & $673 / 2.29$ & & $1,402 / 2.24$ & & $1,129 / 2.31$ \\
\hline
\end{tabular}

aduplicate; ${ }^{\mathrm{b}}$ quintuplicate; ${ }^{\mathrm{c} 20}$ times; ${ }^{\mathrm{d} 2}$-mm mesh; ${ }^{\mathrm{e}} 4-\mathrm{mm}$ mesh.

${ }^{1} \mathrm{M}=$ Mash diet; $\mathrm{CM}=$ Mash diet conditioned at $60^{\circ} \mathrm{C} ; \mathrm{P} 2.5=$ Diet conditioned at $60^{\circ} \mathrm{C} /$ pelleted $/ 2.5$-mm matrix; $\mathrm{P} 2.5 \mathrm{C}=$ Diet conditioned at $60^{\circ} \mathrm{C} /$ pelleted $/ 2.5-\mathrm{mm}$ matrix and crumbled; $\mathrm{P} 4.75=$ Diet conditioned at $60^{\circ} \mathrm{C} /$ pelleted $/ 4.75-\mathrm{mm}$ matrix; $\mathrm{P} 4.75 \mathrm{C}=$ Diet conditioned at $60^{\circ} \mathrm{C} /$ pelleted $/ 4.75-\mathrm{mm}$ matrix and crumbled.

The PDI and pellet hardness were higher in the P2.5 diet compared to the P4.75, which agrees with the results reported by Chae et al. (1998), who also found that PDI and hardness were higher in the pellets of smaller diameter. The lower the PDI and pellet hardness, the higher the percentage of fines is, a fact that was corroborated in the present study because the percentage of fines was higher in the P4.75 diet compared to the P2.5. Several studies showed that the higher the percent fines of a diet, the poorer the pigs' performance and/or FC (STARK et al., 1993). However, a significant difference in the performance parameters was not found between the P2.5 and P4.75 diets (Table 5). Furthermore, the presence of fines in feeders might result in feed wastage, animal refusals and increased feeder management (WONDRA et al., 1995; BEHNKE, 2001).

As observed in Table 5, a difference was not found in the parameters of DWG and DFI in the period from 21 to 39 days of age. Table 5 also shows that pelleting promoted a reduction of $\mathrm{FC}$ and that the P2.5 diet exhibited the best FC. The highest FC values were observed in the $\mathrm{M}$ and $\mathrm{CM}$ diets. According to some authors, pigs fed a pelleted diet have greater daily gain (STARK et al., 1994; LAITAT et al., 1999; HANCOCK; BEHNKE, 2001; OHH et al., 2002; XING et al., 2004) and improved feed efficiency (JENSEN; BECKER, 1965; PATTERSON, 1983; STARK et al., 1994; SAWYER et al., 1999; HANCOCK; BEHNKE, 2001; OHH et al., 2002; XING et al., 2004; SALA; DELIA, 2012) compared with pigs fed a mash diet. The improvement in performance of pigs fed pelleted diets rather than mash diets may be a result of improved nutrient digestibility (MEDEL et al., 2004; XING et al., 2004), improved palatability (SKOCH et al., 1983a,b; BEHNKE, 2001; CHAE; HAN, 1998; SOLÀ-ORIOL et al., 2009), destruction of pathogenic organisms (SKOCH et al., 1983b; BEHNKE, 2001), starch and protein modification (SKOCH et al., 1983b; BEHNKE, 2001) and reduced time to consume the feed (BEHNKE, 2001; 
LAITAT et al., 1999). However, according Wondra et al. (1995), Hancock and Behnke (2001) and Medel et al. (2004), pelleting pig diets is known to induce greater benefits in terms of waste reduction than improved animal performance.

Table 5. Zootechnical performance of piglets fed mash (M), conditioned mash (CM), pelleted to $2.5 \mathrm{~mm}(\mathrm{P} 2.5)$, pelleted to $2.5 \mathrm{~mm}$ and crumbled (P2.5C), pelleted to $4.75 \mathrm{~mm}$ (P4.75) and pelleted to 4.75 and crumbled (P4.75C) diets (means $\pm \mathrm{SE}$ ).

\begin{tabular}{|c|c|c|c|c|c|c|c|}
\hline \multirow[b]{2}{*}{ Traits $^{1}$} & \multicolumn{6}{|c|}{ Treatment } & \multirow[b]{2}{*}{$P$} \\
\hline & $\mathrm{M}$ & $\mathrm{CM}$ & P2.5 & $\mathrm{P} 2.5 \mathrm{C}$ & $\mathrm{P} 4.75$ & $\mathrm{P} 4.75 \mathrm{C}$ & \\
\hline BW & $1.57 \pm 0.06$ & $1.61 \pm 0.06$ & $1.67 \pm 0.06$ & $1.56 \pm 0.06$ & $1.68 \pm 0.06$ & $1.71 \pm 0.07$ & 0,09 \\
\hline WW & $7.18 \pm 0.31$ & $7.17 \pm 0.30$ & $7.20 \pm 0.29$ & $7.19 \pm 0.29$ & $7.19 \pm 0.31$ & $7.17 \pm 0.31$ & 0.94 \\
\hline DFI / FM & $349 \pm 18.3$ & $340 \pm 17.9$ & $336 \pm 21.5$ & $342 \pm 26.5$ & $358 \pm 12.9$ & $343 \pm 16.9$ & 0.91 \\
\hline DFI / DM & $311 \pm 17.1$ & $294 \pm 15.7$ & $297 \pm 19.2$ & $302 \pm 23.6$ & $312 \pm 11.3$ & $300 \pm 14.9$ & 0.87 \\
\hline DWG & $266 \pm 23.9$ & $232 \pm 22.3$ & $287 \pm 25.3$ & $275 \pm 37.3$ & $277 \pm 23.4$ & $268 \pm 22.5$ & 0.23 \\
\hline $\mathrm{FC} / \mathrm{FM}$ & $1.48 \pm 0.04^{\mathrm{ab}}$ & $1.56 \pm 0.04^{\mathrm{a}}$ & $1.32 \pm 0.03^{\mathrm{c}}$ & $1.42 \pm 0.07^{\mathrm{abc}}$ & $1.41 \pm 0.04^{\mathrm{bc}}$ & $1.44 \pm 0.04^{\mathrm{abc}}$ & $<0.01$ \\
\hline $\mathrm{FC} / \mathrm{DM}$ & $1.31 \pm 0.03^{\mathrm{a}}$ & $1.36 \pm 0.04^{\mathrm{a}}$ & $1.17 \pm 0.02^{\mathrm{b}}$ & $1.25 \pm 0.06^{\mathrm{ab}}$ & $1.23 \pm 0.04^{\mathrm{ab}}$ & $1.26 \pm 0.04^{\mathrm{ab}}$ & $<0.01$ \\
\hline W 39 & $11.97 \pm 0.53^{\mathrm{ab}}$ & $11.34 \pm 0.44^{\mathrm{b}}$ & $12.36 \pm 0.63^{\mathrm{a}}$ & $12.15 \pm 0.73^{\mathrm{a}}$ & $12.18 \pm 0.40^{\mathrm{a}}$ & $12.00 \pm 0.52^{\mathrm{ab}}$ & 0.04 \\
\hline \multicolumn{8}{|c|}{ Residual effect (mash diet) } \\
\hline DFI & $1018 \pm 0.03$ & $958 \pm 0.02$ & $1020 \pm 0.04$ & $1005 \pm 0.05$ & $1012 \pm 0.02$ & $1022 \pm 0.05$ & 0.68 \\
\hline DWG & $653 \pm 21.5$ & $626 \pm 15.9$ & $645 \pm 30.4$ & $633 \pm 24.4$ & $638 \pm 14.8$ & $652 \pm 29.6$ & 0.89 \\
\hline $\mathrm{FC}$ & $1.56 \pm 0.03$ & $1.53 \pm 0.02$ & $1.58 \pm 0.03$ & $1.58 \pm 0.03$ & $1.59 \pm 0.03$ & $1.57 \pm 0.03$ & 0.63 \\
\hline W 53 & $21.11 \pm 0.70$ & $20.12 \pm 0.54$ & $21.40 \pm 0.93$ & $21.02 \pm 0.99$ & $21.11 \pm 0.51$ & $21.12 \pm 0.81$ & 0.48 \\
\hline
\end{tabular}

${ }^{\mathrm{a}-\mathrm{c}}$ Means within a row with different superscripts differ $(P<0.05)$.

${ }^{1} \mathrm{BW}=$ birth weight; WW = weight at weaning; DFI = daily feed intake; DWG = daily weight gain; $\mathrm{FC}=\mathrm{feed}$ conversion; $\mathrm{FM}=$ fresh mass; DM = dry mass; W $39=$ weight at 39 days of age; W $53=$ weight at 53 days of age.

Diet dry mass: $\mathrm{M}-88.96 \%$; CM $-86.66 \%$; P2.5 - 88.26\%; P2.5C - 88.34\%; P4.75-87.17\%; and P4.75C - 87.40\%.

Surek (2012) found improvement of FC among nursery pigs fed a pelleted diet compared to the ones fed a mash diet, and attributed this finding to the greater amount of waste associated with the use of the mash diet and the greater digestible energy exhibited by the pelleted diet. In the present study, no waste was available for measurement, as the trough feeder was designed to avoid waste. This finding shows that the better FC exhibited by the animals fed pelleted diets was not due to less wastage, but to the differentiated processing, which exerted positive influence on the digestibility of the diets (Table 6). Traylor et al. (1996), Medel et al. (2004) and Neta (2015) found that while pelleting improved FC among nursery pigs, no difference was detected in the DFI or DWG, which was also the case in the present study. However, Costa et al. (2006) found no effects of pelletization on DFI, DWG and FC in nursery pigs.
Zhu et al. (2010) compared nursery pigs fed pelleted or mash diets and found that pelleting significantly improved the FC and DWG, while no difference was found in the DFI, results that were similar to those in the present study. Because pelleting had no effect on DFI, those authors attributed the improvement in FC and DWG to the better digestibility of the nutrients and energy in the pelleted diet.

There are few reports in the literature on the effect of the pellet size on the performance of pigs. According Dong and Pluske (2007), smaller pellet size may result in improved performance of weanling pigs compared with larger pellet size. However, in the present study, no significant difference was found in the investigated performance parameters as a function of the pellet size (2.5 vs. $4.75 \mathrm{~mm})$. Neta (2015), comparing the performance of nursery 
pigs ( 21 to 73 days old) fed $2.2 \mathrm{~mm}$ or $4.0 \mathrm{~mm}$ pellet also didn't find any difference on DFI, DWG and FC. This result corroborates those by Traylor et al. (1996) and Edge et al. (2005), who did not detect any effect of the pellet size on the performance of nursery pigs. Although statistically non-significant, FC was $4.8 \%$ lower among animals fed the P2.5 diet compared to P4.75, which might be due to the lower percent fines in the former (Table 4). Chae et al. (1998) compared pellets of 4.76 and $6.8 \mathrm{~mm}$ in diameter in nursery and growing-finishing pigs. The results did not indicate a significant difference in DWG and DFI; however, animals fed the smaller pellets exhibited better FC compared to the ones fed larger pellets, which is in agreement with the present study.

Lavorel et al. (1982) assessed diets with pellets of 2.5, 3.0 and $5.0 \mathrm{~mm}$ in diameter and found that during the first $2 \mathrm{wk}$ after weaning, the growth rate was better in piglets fed the $2.5-\mathrm{mm}$ pellets compared to the ones given the $5.0-\mathrm{mm}$ pellets. However, no difference was detected during the following $2 \mathrm{wk}$ (35 to 48 days of age). Patridge (1989) observed that compared to the larger pellets $(3.2 \mathrm{~mm})$ and the pelleted/crumbled diet, the smaller pellets $(2.4$ $\mathrm{mm}$ ) had beneficial effects on the FI and WG of the weaned piglets.

Pelleting followed by grinding had no particular beneficial effects because the performance of the animals fed the pelleted/crumbled diets did not differ in comparison to the pigs fed the mash and pelletedonly diets (Table 5). This result corroborates those by Neta (2015), who did not detect any difference on the performance of nursery pigs (21 to 73 days old) fed the pelleted/crumbled diets in comparison to the pigs fed the mash and pelleted-only diets. In addition, grinding increases the percent fines, which might impair the animals' performance, as mentioned above.

Table 5 shows that in the assessment of the residual effects of the diets, when all the animals were fed the mash diet, the FC exhibited a tendency to increase among pigs previously fed pelleted diets compared to pigs fed the mash and conditioned mash diets. This finding might be explained by the change in the physical form of the diet, which might have promoted poorer initial acceptance of the mash diet, thus impairing animal feeding efficiency compared to animals already adapted to the mash diet. Another possible explanation might be the occurrence of a compensatory effect in animals initially given the mash and conditioned mash diets; that is, they exhibited poorer FC in the earlier period, which might have been compensated for in the later period.

No difference was found in the ADMD, ADCGE or ADEDM as a function of the processing and physical form of the diets (Table 6). The ADMD, ADCGE and ADEDM were expected to be superior in the pelleted compared to the mash diets because, as several authors have asserted, pelleting of cornand soybean-based diets increases the energy and digestibility of several nutrients (WONDRA et al., 1995; NOBLET; CHAMPION, 2003; NOBLET; JAGUELIN, 2008; SUREK, 2012).

According to Jensen and Becker (1965), pelletizing gelatinizes starch and makes it more susceptible to enzymatic digestion, thus improving animal performance. Zhu et al. (2010) found that pelleting improved the digestibility of DM, protein, energy and fat, thus agreeing with the reports by Noblet and Champion (2003), Xing et al. (2004) and Noblet and Jaguelin (2008), who used corn- and soybean-based diets. 
Table 6. Apparent dry matter digestibility (ADMD); apparent digestibility coefficient of gross energy (ADCGE); apparent digestible energy in dry matter (ADEDM); and apparent digestibility coefficient of ether extract (ADCEE) of mash (M), conditioned mash (CM), pelleted to $2.5 \mathrm{~mm}(\mathrm{P} 2.5)$ and pelleted to $4.75 \mathrm{~mm}$ (P4.75) diets (means $\pm \mathrm{SE}$ ).

\begin{tabular}{lccccc}
\hline \multicolumn{1}{c}{ Traits } & $\mathrm{M}$ & $\mathrm{CM}$ & $\mathrm{P} 2.5$ & $\mathrm{P} 4.75$ & $P$ \\
\hline ADMD, $\mathrm{g} / \mathrm{kg}$ & $868.8 \pm 6.0$ & $854.4 \pm 4.9$ & $850.3 \pm 7.4$ & $862.5 \pm 6.6$ & 0.254 \\
ADCGE, $\mathrm{g} / \mathrm{kg}$ & $864.9 \pm 5.3$ & $860.6 \pm 5.1$ & $868.7 \pm 6.9$ & $863.1 \pm 7.4$ & 0.794 \\
ADEDM, $\mathrm{kcal} / \mathrm{kg}$ & $3906 \pm 23$ & $3903 \pm 23$ & $3966 \pm 31$ & $3929 \pm 33$ & 0.214 \\
ADCEE, $\mathrm{g} / \mathrm{kg}$ & $738.9 \pm 16^{\mathrm{b}}$ & $738.1 \pm 9^{\mathrm{b}}$ & $802.9 \pm 26^{\mathrm{a}}$ & $801.9 \pm 17^{\mathrm{a}}$ & 0.042 \\
\hline
\end{tabular}

${ }^{\mathrm{a}-\mathrm{b}}$ Means within a row with different superscripts $\operatorname{differ}(P<0.05)$.

The ADCEE was superior among animals fed the pelleted diets compared to those fed the mash diets $(\mathrm{P} \leq 0.05)$. This finding agrees with the results reported by Zhu et al. (2010), who observed $81.84 \%$ digestibility of ether extract with mash diet and $88.74 \%$ with pelleted diet; that is, an approximately $7 \%$ increase in digestibility was observed with the pelleted diet, similar to the increase found in the present study. Le Gall et al. (2009) found that pelleting improved moderately the digestibility of energy and organic matter $(+1.5 \%$ and $+1.0 \%$, respectively; $\mathrm{P}<0.05)$ in connection with greater fat digestibility $(+25 \%)$.

The improved digestibility of the pelleted diets might be related to the increased availability of intracellular corn oil, which results from the greater abrasion that takes place during the pelleting process and thus better utilization of that nutrient (GONZALEZ-ESQUERRA; LEESON, 2000). Similar results were obtained in broilers because ether extract digestibility was better among chickens fed pelleted diets compared to those fed mash diets (ZELENKA, 2003; LARA et al., 2013).

As the physical form of the diets had no effect on the DFI, the FC improvement exhibited by animals fed the pelleted P2.5 diet might be attributed to the feed processing, which afforded greater digestibility of ether extract (Table 6). As no difference in performance was detected between pigs fed pellets that were 2.5 or $4.75 \mathrm{~mm}$ in diameter (Table 5), one might infer that the production of the 4.75 $\mathrm{mm}$ pellets has a better cost-benefit ratio due to its greater production efficiency (Table 3).

\section{Conclusions}

In conclusion, the processing and physical form of the diets had no effect on the DWG and DFI of the 21- to 39-day-old piglets. The 2.5-mm-diameter pellets induced better FC compared to the mash and conditioned mash diets, which might be attributed to the better digestibility of the ether extract exhibited by the pelleted diets. Pellet size had no effect on the investigated performance parameters. Therefore, the production of the $4.75 \mathrm{~mm}$ pellets had a better costbenefit ratio due to its greater production efficiency.

\section{Acknowledgements}

The authors are grateful to Brazilian Agricultural Research Corporation (Empresa Brasileira de Pesquisa Agropecuária - EMBRAPA) for funding this study.

\section{References}

BEHNKE, K. C. Processing factors influencing pellet quality. Animal Feed Science and Technology, Amsterdam, v. 5, n. 4, p. 19-22, 2001.

CHAE, B. J.; HAN, IN K. Processing effects of feeds in swine: review. Asian-Australasian Journal of Animal Sciences, Seoul, v. 11, n. 5, p. 597-607, 1998.

CHAE, B. J.; KANG, H. I.; HAN, I. K.; CHO, W. T.; KIM, J. H.; CHUNG, Y. K.; SHIM, M. S. The effects of corn particle size and pellet size on growth and carcass traits in growing-finishing pigs. Korean Journal of Animal Nutrition and Feedstuffs, Seoul, v. 22, n. 1, p. 81-86, 1998. 
COSTA, E. R.; SILVA, L. P. G.; SILVA, J. H. V.; CARVALHO, L. E.; CARVALHO, M. X. C. Desempenho de leitões alimentados com diversas formas físicas da ração. Ciência Animal Brasileira, Goiânia, v. 7, n. 3, p. 241-247, 2006.

DONG, G. Z.; PLUSKE, J. R. The low feed intake in newly-weaned pigs: Problems and possible solutions. Asian-Australasian Journal of Animal Sciences, Seoul, v. 20, n. 3, p. 440-452, 2007.

EDGE, H. L.; DALBY, J. A.; ROWLINSON, P.; VARLEY, M. A. The effect of pellet diameter on the performance of young pigs. Livestock Production Science, Amsterdam, v. 97, n. 2-3, p. 203-209, 2005.

GONZALEZ-ESQUERRA, R.; LEESON, S. Studies on the metabolizable energy content of ground full-fat flaxseed fed in mash, pellet, and crumbled diets assayed with birds of different ages. Poultry Science, Savoy, v. 79, n. 11, p. 1603-1607, 2000.

HANCOCK, J. D.; BEHNKE, K. C. Use of ingredient and diet processing technologies (grinding, mixing, pelleting, and extruding) to produce quality feeds for pigs. In: LEWIS, A. J.; SOUTHERN, L. L. (Ed.). Swine nutrition. Boca Raton: CRC Press, 2001. p. 469-497.

JENSEN, A. H.; BECKER, D. E. Effect of pelleting diets and dietary components on the performance of young pigs. Journal of Animal Science, Champaign, v. 24, n. 1, p. 392-397, 1965.

KIL, D. Y.; STEIN, H. H. Invited review: management and feeding strategies to ameliorate the impact of removing antibiotic growth promoters from diets fed to weanling pigs. Canadian Journal of Animal Science, Ottawa, v. 90, n. 4, p. 447-460, 2010.

LAITAT, M.; VANDENHEEDE, M.; DESIRON, A.; CANART, B.; NICKS, B. Comparison of performance, water intake and feeding behaviour of weaned pigs given either pellets or meal. Animal Science, Wallingford, v. 69, n. 3, p. 491-499, 1999.

LARA, L. J. C.; CAMPOS, W. E.; BAIÃO, N. C.; LANA, A. M. Q.; CANÇADO, S. V.; ROCHA, J. S. R.; POMPEU, M. A.; BARBOSA, V. M. Efeitos da forma física da ração e da linhagem de frangos de corte sobre a digestibilidade dos nutrientes e determinação de energia líquida. Arquivo Brasileiro de Medicina Veterinária e Zootecnia, Belo Horizonte, v. 65, n. 6, p. 1849-1857, 2013.

LAVOREL, O.; FEKETE, J.; LEUILLET, M. A comparative study concerning the utilization of pellets of different diameters by the weaned piglet. Annales de Zootechnie, INRA/EDP Sciences, Essonne, v. 31, n. 3, p. 338-339, 1982.
LE GALL, M.; WARPECHOWSKI, M.; JAGUELINPEYRAUD, Y.; NOBLET, J. Influence of dietary fibre level and pelleting on the digestibility of energy and nutrients in growing pigs and adult sows. Animal: an International Journal of Animal Bioscience, Cambridge, v. 3, n. 3, p. 352-359, 2009.

MEDEL, P.; LATORRE, M. A.; DE BLAS, C.; LÁZARO, R.; MATEOS, G. G. Heat processing of cereals in mash or pellet diets for young pigs. Animal Feed Science and Technology, Amsterdam, v. 113, n. 1-4, p. 127-140, 2004.

NETA, C. S. S. Granulometria e processamento de dietas para leitões dos 23 aos 71 dias de idade. 2015. Dissertação (Mestrado em Zootecnia) - Escola de Veterinária, Universidade Federal de Minas Gerais, UFMG, Belo Horizonte.

NOBLET, J.; CHAMPION, M. Effect of pelleting and body weight on digestibility of energy and fat of two corns in pigs. Journal of Animal Science, Champaign, v. 81, n. 1, p. 140-143, 2003.

NOBLET, J.; JAGUELIN, Y. Effect of pelleting and fat content on energy value of corn in pigs. Journal of Animal Science, Champaign, v. 86, p. 574-575, 2008. Supplement 1.

OHH, S. H.; HAN, K. N.; CHAE, B. J.; HAN, IN K.; ACDA, S. P. Effects of feed processing methods on growth performance and ileal digestibility of amino acids in young pigs. Asian-Australasian Journal of Animal Sciences, Seoul, v. 15, n. 12, p. 1765-1772, 2002.

PATRIDGE, I. G. Alternative feeding strategies for weaner pigs. In: BARNETT, J. L.; HENNESSEY, D. P. (Ed.). Manipulation of pig production. Victoria: Australasian Pig Science Association, 1989. p. 160-169.

PATTERSON, D. C. The response of pigs weaned at 12 to 19 days of age to different physical forms of a dry diet given ad libitum. Animal Production, Central Java, v. 36, n. 1, p. 524-525, 1983.

ROSENTRATER, K. A. Understanding distiller's grain storage, handling, and flowability challenges. Distiller's Grains Quarterly, Flórida, v. 1, n. 1, p. 18-21, 2006.

SALA, F.; DELIA, E. The effect of pellet feed on the performance and nutrient's digestibility of weaned piglets. Albanian Journal of Agricultural Sciences, Tirana, v. 11, n. 4, p. 275-278, 2012.

SAWYER, J. T.; WOODWORTH, J. C.; O'QUINN, P. R.; NELSSEN, J. L.; TOKACH, M. D.; GOODBAND, R. D.; DRITZ, S. S. Effects of diet processing method on growth performance of segregated early-weaned pigs. Manhattan: Kansas State University Swine Day Report, 
1999. p. 72-75. Available at: <http://www.ksre.ksu.edu/ library/lvstk2/srp841.pdf $>$. Accessed at: 15 fev. 2016.

SILVA, D. J. Análise de alimentos: métodos químicos e biológicos. Viçosa, MG: Universidade Federal de Viçosa, 1990. $165 \mathrm{p}$.

SKOCH, E. R.; BINDER, S. F.; DEYOE, C. W.; ALLEE, G. L.; BEHNKE, K. C. Effects of pelleting conditions on performance of pigs fed a corn-soybean meal diet. Journal of Animal Science, Champaign, v. 57, n. 4, p. 922-928, 1983a.

Effects of steam pelleting conditions and extrusion cooking on a swine diet containing wheat middlings. Journal of Animal Science, Champaign, v. 57, n. 4, p. $929-935,1983 b$.

SOLÀ-ORIOL, D.; ROURA, E.; TORRALLARDONA, D. Feed preference in pigs: effect of cereal sources at different inclusion rate. Journal of Animal Science, Champaign, v. 87, n. 2, p. 562-270, 2009.

STARK, C. R.; BEHNKE, K. C.; HANCOCK, J. G.; HINES, R. H. Pellet quality affects growth performance of nursery and finishing pigs. In: SWINE DAY, 1993, Manhattan, Kansas. Proceedings... Kansas: Manhattan, 1993. p. 71-74.

STARK, C. R.; BEHNKE, K. C.; HANCOCK, J. D.; TRAYLOR, S. L.; HINES, R. H. Effect of diet form and fines in pelleted diets on growth performance of nursery pigs. Journal of Animal Science, Champaign, v. 72, n. 1, p. 214-219, 1994.

STEIDINGER, M. U.; GOODBAND, R. D.; TOKACH, M. D.; DRITZ, S. S.; NELSSEN, J. L.; MCKINNEY, L. J.; BORG, B. S.; CAMPBELL, J. M. Effects of pelleting and pellet conditioning temperatures on weanling pig performance. Journal of Animal Science, Champaign, v. 78, n. 12, p. 3014-3018, 2000.
SUREK, D. Peletização de dietas pré-iniciais para leitões desmamados. 2012. Dissertação (Mestrado em Ciências Veterinárias) - Programa de Pós-Graduação em Ciências Veterinárias do Setor de Ciências Agrárias. Universidade Federal do Paraná, Curitiba.

TRAYLOR, S. L.; BEHNKE, K. C.; HANCOCK, J. D.; SORRELL, P.; HIPES, R. H. Effects of pellet size on growth performance in nursery and finishing pigs. Journal of Animal Science, Champaign, v. 74, n. 1, p. 67, 1996.

WONDRA, K. J.; HANCOCK, J. D.; BEHNKE, K. C.; HINES, R. H.; STARK, C. R. Effects of particle size and pelleting on growth performance, nutrient digestibility, and stomach morphology in finishing pigs. Journal of Animal Science, Champaign, v. 73, n. 3, p. 757-763, 1995.

XING, J. J.; VAN HEUGTEN, E.; LIT, D. F.; TOUCHETTE, K. J.; COALSON, J. A.; ODGAARD, R. L.; ODLE, J. Effects of emulsification, fat encapsulation, and pelleting on weanling pig performance and nutrient digestibility. Journal of Animal Science, Champaign, v. 82, n. 9, p. 2601-2609, 2004.

ZANOTTO, D. L.; KRABBE, E. L.; ALBINO, J. J.; CARDOSO, L. S. Granucalc: software de granulometria. Concórdia: Embrapa Suínos e Aves, 2013. 2 p.

ZANOTTO, D. L.; BELLAVER, C. Método de determinação da granulometria de ingredientes para uso de rações de suínos e aves. Concordia: EmbrapaCNPSA, 1996. 5 p.

ZELENKA, J. Effect of pelleting on digestibility and metabolizable energy values of poultry diet. Journal of Animal Science, Champaign, v. 48, n. 6, p. 239-242, 2003.

ZHU, Z.; HINSON, R. B.; MA, L.; LI, D.; ALLEE, G. L. Growth performance of nursery pigs fed $30 \%$ distillers dried grain with solubles (DDGS) and the effects of pelleting on performance and nutrient digestibility. Asian-Australas. Journal of Animal Science, Champaign, v. 23, n. 6, p. 792-798, 2010. 